\title{
The association between magnitude of T-SPOT.TB and clinical characteristics in active pulmonary tuberculosis: a retrospective multicenter investigation
}

\section{Yunqing Chang}

Beijing Chest Hospital

Wanli Kang

Beijing Chest Hospital

Meiying Wu

Souzhou 5th People's Hospital

\section{A Ertai}

Chest Hospital of Xinjiang Uygur Autonomous Region

\section{Shucai Wu}

Hebei Chest Hospital

\section{Zhihui Li}

Hebei Chest Hospital

\section{Shujun Geng}

Heibei Chest Hospital

\section{Mingwu Li}

Kunming 3rd People's Hospital

\section{Liang Li}

Beijing Chest Hospital

Shenjie Tang ( $\nabla$ tangsj1106@hotmail.com )

\section{Research article}

Keywords: Active Pulmonary Tuberculosis, Interferon-Gamma Release Assay, Diagnosis, T-SPOT.TB

Posted Date: September 4th, 2019

DOl: https://doi.org/10.21203/rs.2.10775/v1

License: (a) This work is licensed under a Creative Commons Attribution 4.0 International License. Read Full License 


\section{Abstract}

Background: The aim of this study was to evaluate the association between magnitude of T-SPOT.TB and clinical characteristics in active pulmonary tuberculosis. Methods: In this retrospective multicenter investigation, the medical records' archives of PTB patients were reviewed. Data including gender, age group, bacterial culture, sputum-smear microscopy, lung cavity and range of PTB were extracted from the records. The Jonckheere-Terpstra test and chi-square test for trend were used to evaluate the association between magnitude of T-SPOT.TB and clinical characteristics in active pulmonary tuberculosis. Results: A total of 1252 PTB patients were included in this study.Chi-square trend tests revealed significant positive trends between bacterial culture and magnitude of T-SPOT.TB A ( $\chi 2=18.978, P<0.001)$ or T-SPOT.TB B $(X 2=19.677, P<0.001)$. There were significant positive trends between AFB and magnitude of T-SPOT.TB A (TJT $=345784, \mathrm{P}<0.001)$ or T-SPOT.TB B (TJT $=336017, \mathrm{P}<0.001)$. There was a significant positive trend between range of lung cavity and magnitude of T-SPOT.TB A (TJT $=326079.5, P=0.023)$. There were significant negative trends between age group and magnitude of T-SPOT.TB A (TJT =204306, $P$ $<0.001)$ or T-SPOT.TB B (TJT $=206572, \mathrm{P}<0.001)$. Conclusions: The magnitude of T-SPOT.TB in PTB patients may reflect the condition of the patients and could be helpful for clinicians to assess the degree of infection and lung tissue damage.

\section{Background}

Tuberculosis (TB) has existed for millennia and remains a major global health problem. It caused illhealth for approximately 10 million people in 2017[1]. TB is also a serious problem in China. Rapidly detecting infection by the causative bacterium, Mycobacterium tuberculosis (MTB) is important for controlling and preventing TB. A recent breakthrough in the diagnosis of TB and latent TB infection was the introduction of interferon-gamma release assays (IGRAs), in which the production of interferongamma (IFN- $\gamma$ ) in response to MTB-specific antigens is measured. MTB-specific antigens refer to early secreted antigenic target-6kD (ESAT-6) and culture filtrate protein-10kD (CFP-10)[2]. These proteins are encoded by the RD-1 genomic segment.Comparative genomics of the $M$. tuberculosis complex revealed that overlapping portions of RD1are absent from the attenuated or avirulent strains $M$. bovis BCG, $M$. microti and the Dassie bacillus, but are present in all fully virulent isolates. Therefore区ESAT- 6 and CFP-10 play an important role in the virulence of MTB. Several studies have demonstrated that IGRAs may be useful as

supplemental tools in the diagnosis of active TB[3]. There are currently two types of commercial IGRAs available: the QuantiFERON-TB Gold In-Tube test and the T-SPOT.TB blood test[4]. The magnitude of TSPOT.TB A reflects the number of SFUs formed by IFN-gamma released by PBMCs stimulated by ESAT-6. Meanwhile, the magnitude of T-SPOT.T B reflects the number of SFUs formed by IFN-gamma released by PBMCs stimulated by CFP-10. Therefore, the magnitude of T-SPOT.TB A or B may be related to the virulence of Mycobacterium tuberculosis, thus contributing to the assessment of tuberculosis. However, the association between magnitude of T-SPOT.TB and clinical characteristics in active pulmonary tuberculosis are not yet clear. In this study, we conducted a large retrospective multicenter investigation in 
China to evaluate the association between magnitude of T-SPOT.TB and clinical characteristics in active PTB.

\section{Methods}

\section{Study design and participants}

The study was performed at 5 specialized TB hospitals in China. Diagnosis of TB refers to Clinical diagnosis standard of TB issued by Chinese Medical Association[5]. The PTB patients who underwent valid T-SPOT.TB assays, bacterial culture, sputum-smear microscopy and X-ray examination from December 2012 to November 2015 in the five hospitals and met the study criteria were retrospectively evaluated. The five hospitals are situated in the south, north, east, and center of China. At each study hospital, trained health workers extracted data from the medical records of inpatients. Records were collected in terms of sputum smear/culture, range of pulmonary tuberculosis, range of lung cavity, age, gender, etc. All cases had negative results on serological tests for HIV. All patients had not had immune diseases or received immunosuppressant before.

\section{T-SPOT.TB assay}

The T-SPOT.TB test (Oxford Immunotec Ltd., UK) was performed using peripheral blood mononuclear cells (PBMCs) separated from heparinized blood samples according to the manufacturer's instructions. Briefly, PBMCs were isolated and incubated with two antigens in parallel (peptides derived from early secreted antigenic target- 6 ESAT- 6 and from culture filtrate protein CFP-10). The procedure was performed in plates pre-coated with anti-IFN-y antibodies at $37^{\circ} \mathrm{C}$ for $16-20 \mathrm{~h}$. After application of alkaline phosphatase-conjugated secondary antibody and chromogenic substrate, the number of spot-forming units (SFUs) was counted using an automated ELISpot counter. The test result of T-SPOT.TB assay include Panel A (containing peptide antigens derived from ESAT-6) and Panel B (containing peptide antigens derived from CFP-10). The results were interpreted as recommended by the test kit manufacturer[6]. The magnitude of T-SPOT.TB A and B were divided into the following five groups according to the number of Spot-Forming Units (SFUs): 0-5 SFUs group, 6-19 SFUs group, 20-39 SFUs group, 40-69 SFUs group and $\geq 70$ SFUs group, which the positive magnitudes of T-SPOT.TB A and B were classified by quartile and integers.

\section{Statistical analysis}

We took some measures to guarantee the data quality, including a standardized study protocol and standardized training of research staff. Descriptive statistics including frequency distribution and median and interquartile were used to report study findings. The T-SPOT.TB results were evaluated in the subgroups of gender, age, bacterial culture, sputum-smear microscopy, range of PTB disease, range of lung cavity. The scatterplot were used to describe the trends between T-SPOT.TB and clinical characteristics. Jonckheere-Terpstra test(JT),a nonparametric trend test appropriate for ordinal variables, has higher test efficiency on the premise of overall priori ranking.So the trends and association between 
ordinal variables were assessed using the Jonckheere-Terpstra test and Spearman rank order correlation test. The differences and trends between bacterial culture, gender and T-SPOT.TB were assessed using the chi-square test and chi-square test for trend. All data were collected in datasheets in MS Office Excel (Microsoft, Redmond, WA, USA) and all analyses were conducted using SPSS software for Windows, version 13 (Chicago, USA). A $P$ value $<0.05$ was considered as statistically significant in all analyses.

\section{Results}

\section{Demographic and clinical characteristics of the PTB patients}

A total of 1252 eligible PTB patients were included during the study period with a median age of 42 (2559) years, and $67.7 \%$ of whom were male. The proportion with culture-positive PTB was $57.2 \%$. The demographics and clinical characteristics of the study population are presented in Table 1.

\section{The association and trends between sputum-smear microscopy and T-SPOT.TB}

There was a low but significant correlation between sputum-smear microscopy (AFB) and T-SPOT.TB A ( $r_{s}$ $=0.141, P<0.001)$ or T-SPOT.TB B $\left(r_{s}=0.121, P<0.001\right)$, respectively.

The trends between sputum-smear microscopy and T-SPOT.TB A, B were shown in Fig1 and Fig2. There was a significant positive trend between AFB and T-SPOT.TB A $\left(T_{J T}=345784, P<0.001\right)$ or T-SPOT.TB B $\left(T_{\text {JT }}=336017, P<0.001\right)$. The Jonckheere-Terpstra test also demonstrated trends toward increasing magnitudes of T-SPOT.TB A and T-SPOT.TB B with increasing positive magnitudes of AFB (Tables 2,3).

\section{The association and trends between bacterial culture and T-SPOT.TB}

The positive magnitudes of T-SPOT.TB A $\left(\chi^{2}=19.835, P=0.001\right)$ and T-SPOT.TB B $\left(\chi^{2}=22.952, P<0.001\right)$ were significantly different between culture-positive and culture-negative PTB patients.

The trends between bacterial culture and T-SPOT.TB A, B were shown in Fig3 and Fig4. There were significant positive trends between bacterial culture and positive magnitudes of T-SPOT.TB A $\left(X^{2}=18.978\right.$, $P<0.001)$ or T-SPOT.TB B $\left(X^{2}=19.677, P<0.001\right)$, and the chi-square test for trend demonstrated trends toward increasing positive magnitudes of T-SPOT.TB A and T-SPOT.TB B with increasing positive rate of bacterial culture (Table 2,3).

The association and trends between the range of PTB and T-SPOT.TB 
The Spearman rank order correlation test showed almost no association between range of TB and TSPOT.TB A $\left(r_{s}=0.040, P=0.155\right)$ or T-SPOT.TB B $\left(r_{s}=0.035, P=0.220\right)$.

The trends between range of PTB and T-SPOT.TB A, B were shown in Fig5 and Fig6. Similarly, the Jonckheere-Terpstra test found almost no trend between range of TB and T-SPOT.TB A $\left(T_{J T}=321236.5, P\right.$ $=0.154)$ or T-SPOT.TB B $\left(T_{J T}=315197.5, P=0.219\right)($ Tables 2,3$)$.

\section{The association and trends between the range of lung cavity and T-SPOT.TB}

There was a low but positive correlation between range of lung cavity and T-SPOT.TB A $\left(r_{s}=0.064, P\right.$ $=0.024)$. However, there was almost no association between range of lung cavity and T-SPOT.TB B $\left(r_{S}\right.$ $=0.028, P=0.330$ ).

The trends between range of lung cavity and T-SPOT.TB A, B were shown in Fig7 and Fig8. There was a significant positive trend between range of lung cavity and T-SPOT.TB A ( $\left.T_{J T}=326079.5, P=0.023\right)$. In contrast, there was no trend between range of lung cavity and T-SPOT.TB B $\left(T_{J T}=313180, P=0.322\right)$. The Jonckheere-Terpstra test also demonstrated trends toward increasing positive magnitudes of T-SPOT.TB A with increasing positive magnitudes of range of lung cavity (Tables 2,3).

\section{The association and trends between gender and T-SPOT.TB}

The positive magnitudes of T-SPOT.TB results were not significantly different between male and female groups, T-SPOT.TB A $\left(\chi^{2}=0.295, P=0.990\right)$ and T-SPOT.TB B $\left(\chi^{2}=7.357, P=0.118\right)$ respectively.

The trends between gender and T-SPOT.TB A, B were shown in Fig9 and Fig10.

There was no significant trend between gender and magnitude of T-SPOT.TB A $\left(\chi^{2}=0.028, P=0.868\right)$ or TSPOT.TB B $\left(\chi^{2}=0.783, P=0.376\right)$ (Tables 2,3$)$.

\section{The association and trends between age groups and T-SPOT.TB}

There was a weak negative correlation between age group and T-SPOT.TB A $\left(r_{s}=-0.124, P<0.001\right)$ or TSPOT.TB B $\left(r_{s}=-0.115, P<0.001\right)$.

The trends between age and T-SPOT.TB A, B were shown in Fig11 and Fig12.

There were significant negative trends between age and T-SPOT.TB A $\left(T_{J T}=204306, P<0.001\right)$ or TSPOT.TB B $\left(T_{J T}=206572, P<0.001\right)$. The Jonckheere-Terpstra test also demonstrated trends toward 
decreasing positive magnitudes of T-SPOT.TB A and T-SPOT.TB B with increasing age (Tables 2,3).

\section{Discussion}

Despite substantial progress to combat TB, TB remains a major global health problem in the world. Recently, interferon-y assays have emerged as immunodiagnostic tools to detect tuberculous infection. TSPOT.TB assays use the M. tuberculosis-specific antigenic peptides, ESAT-6 andCFP-10, which are not present in Bacille Calmette-Guérin (BCG) strains and most nontuberculous mycobacteria, making them highly specific for detecting TB infection[7]. These proteins are encoded by genes located within the region of difference 1 (RD1) of the $M$. tuberculosis genome. T-SPOT.TB A represents the number of SFUs produced by stimulation with MTB-specific antigens ESAT- 6 and T-SPOT.TB B represents the number of SFUs produced by MTB-specific antigen CFP-10. The purpose of the study was to evaluate the association between T-SPOT.TB assay results and the clinical characteristics in active pulmonary tuberculosis.ESAT- 6 and CFP-10 are of high and TB-specific immunogenicity, not only in mice, where their roles in virulence, pathogenicity and protective immunity have been extensively investigated, but also in man. Several studies have suggested that ESAT- 6 and CFP-10, alone or in combination, induce strong protective T cell immunity during Mtb infection, especially in murine models of TB[8-11]. The antigens ESAT- 6 and CFP-10 were shown to be associated with virulence and pathogenicity of Mtb in murine models [12-17] and some of these studies also indicated mechanisms by which these virulence factors promoted pathogenicity. Clinical observations have been broadly consistent with the findings in mice.

The degree to which the magnitude of the T-SPOT.TB results were found here to be related to other clinical parameters was striking and consistent with the knowledge that the result of infection with $M$. tuberculosis is determined largely by the host immune response[18]. In particular, effector T cell levels in patients have been found positively associated with the mycobacterial antigen load (which reflects bacterial load)[19-20] and quantitative T-cell responses, as measured by the T-SPOT.TB, were previously reported to indicate mycobacterial burden and disease activity[21]. Indeed, Hill et al. reported that there was an association between the state of the disease and the $M$. tuberculosis load and the number of TBspecific T cells that released IFN-gamma in vivo[22] and Qiu et al. found that the positive rate of TSPOT.TB (92.2\%) was higher in culture-positive than culture-negative PTB (70.5\%)[23]. In the present study, the findings were similar. The magnitudes of the T-SPOT.TB in the culture-positive PTB group were significantly higher than those in culture-negative PTB group. With increasing magnitude of T-SPOT.TB, the positive magnitude of bacterial culture and AFB increased, although the relationship between sputumsmear microscopy (AFB) and T-SPOT.TB A, B was not strong. Nevertheless, the results indicated that the magnitude of T-SPOT.TB may indirectly reflect the bacteria burdens of PTB patients, which is helpful for clinicians to assess the degree of infection.

Relatively few studies have sought an association between the clinical range of PTB disease and magnitude of T-SPOT.TB. Our study found there was almost no association or trend between range of PTB and either magnitude of T-SPOT.TB A or T-SPOT.TB B. 
Liquefaction of solid caseous tuberculous lesions and the subsequent cavity formation are probably the most dangerous processes in the pathogenesis of human pulmonary tuberculosis. Our results suggested there was a significant positive trend between range of lung cavity and T-SPOT.TB A $\left(T_{J T}=326079.5, P\right.$ $=0.023$ ). Furthermore, with increasing magnitudes of T-SPOT.TB $A$, the positive magnitude of lung cavity increased. Since the magnitudes of T-SPOT.TB A reflect the T cell response to ESAT-6, the finding is consistent with a role of this antigen in virulence and pathogenicity. Wards et al.[24] reported that guinea pigs inoculated with either an ESAT-6 knockout strain of M. tuberculosis or its virulent parent had positive skin test reactions to PPD but only the animals inoculated with the parent strain had positive skin test reactions to ESAT-6. Gross pathology, histopathology and mycobacterial culture of tissues indicated that the knockout strain was less virulent than its parent. In contrast to our findings with T-SPOT.TB A, there was almost no association between the range of lung cavity and T-SPOT.TB B. This could imply that there is no role of the T cell response to CFP-10 in cavity development. It may be relevant that Berhet FX et al. [25] reported that recombinant CFP-10, produced in E. coli, did not seem to provide a major target for the humoral immune response that had been generated during human tuberculosis. Thus the magnitude of T-SPOT.TB A, but not T-SPOT.TB B, may indirectly reflect the cavity range of PTB patients, which would be helpful for clinicians in assessing the degree of lung tissue damage in such patients.

Our study showed that the magnitudes of T-SPOT.TB in males were not significantly different from those in females (T-SPOT.TB A, $\chi^{2}=0.295, P=0.990 ;$ T-SPOT.TB $B, \chi^{2}=7.357, P=0.118$ ). A previous study in China also showed that the positive rate of T-SPOT.TB was not different between male and female in active tuberculosis[26]. Thus we thought that the T-SPOT.TB results may not be influenced by gender in PTB patients.

Our study found here that with increasing age of patient the magnitude of T-SPOT.TB gradually decreased, consistent with the known fact that, due to a decline in the strength of immune responses, older individuals tend to be more susceptible to TB[27-29]. Kobashi et al.[29] reported that the positive rate for both combined and separate ESAT- 6 and CFP-10 antigens of QuantiFERON TB-2G tested in the elderly patients was significantly lower than that in younger patients. In another study conducted by Kobashi et al.[30], increasing age associated with false-negative results in ELISPOT assays. Concern has been expressed that a general decline of immune responsiveness may decrease the sensitivity of IGRAs in aged populations[31]. Accordingly, we suggested that the severity of tuberculosis is not readily assessed in elderly patients by T-SPOT.TB assays.

This study had some limitations. One of the main limitations was the restricted nature of the sample population, which could have affected the results of our analyses when considering the multiple patient levels. The purpose of the study was to analyze the association of magnitude of T-SPOT.TB and clinical characteristics in active pulmonary tuberculosis, but the PTB patients were all inpatients and did not include outpatients. Thus, there was bias in the results. on the other hand, the data were all retrospectively collected and analyzed, which might have had impacts on results.

\section{Conclusions}


In conclusion, despite these limitations, to our knowledge, this study is unique in being a multicenter large-scale investigation to evaluate the association between magnitude of T-SPOT.TB and clinical characteristics in active pulmonary tuberculosis in China. Our study revealed some associations. Thus, with increasing magnitudes of T-SPOT.TB, the positive magnitudes of the bacterial culture and AFB increased. With increase in the magnitude of the T-SPOT.TB A, the range of lung cavity increased. Hence, the magnitude of the T-SPOT.TB in PTB patients may reflect the condition of the patients and could be helpful for clinicians in assessing the degree of infection and lung tissue damage.

\section{Abbreviations}

TB:Tuberculosis;AFB:sputum-smear microscopy; SFUs:spot-forming units;

IGRAs:interferon-gamma release assays; IFN-y:interferon-gamma;

ESAT-6:early secreted antigenic target-6; CFP-10:culture filtrate protein-10;

PBMCs:peripheral blood mononuclear cells

\section{Declarations}

\section{Ethics approval and consent to participate}

This was an observational retrospective study. Given that the medical information of patients was recorded anonymously by case history, which would not bring any risk to the participants, the Ethics Committee of Beijing Chest Hospital, Capital Medical University approved this retrospective study, with a waiver of informed consent from the patients.

\section{Consent to publish}

All authors read and approved the final paper for publication.

\section{Availability of data and materials}

All supporting data in this study can be provided by the corresponding author upon reasonable request.

\section{Competing interests}

The authors declare that there are no actual or potential conflicts of interest in relation to this article. 


\section{Funding}

This work was supported by 'Beijing Municipal Administration of Hospitals' Ascent Plan (No. DFL20181601).

\section{Authors' Contributions}

ST and LL designed the study and supervised the data analysis. MW, EA, SW, SG, ZL, ML, WK contributed in the data collection. WK and YC analysed and interpreted the data. YC wrote the manuscript. ST,LL and WK reviewed the paper critically.

\section{Acknowledgements}

We thank Douglas Lowrie of Shanghai Public Health Clinical Center for his invaluable help editing the manuscript.

\section{Authors' Information}

${ }^{1}$ Beijing Chest Hospital, Capital Medical University, Beijing Tuberculosis and Thoracic Tumor Research Institute, Beijing101149, China; ${ }^{2}$ Souzhou $5^{\text {th }}$ People's Hospital, Souzhou 215000 , China; ${ }^{3}$ Chest Hospital of Xinjiang Uygur Autonomous Region, Urumqi 830049, China; ${ }^{4}$ Hebei Chest Hospital, Shijiazhuang 050041, China; ${ }^{5}$ Kunming $3^{\text {rd }}$ People's Hospital, Kunming 650041, China.

Yunqing Chang, Wanli Kang contributed equally to the paper and are both first authors *Corresponding author: Shenjie Tang, Email: tangsj1106@hotmail.com; Liang Li, E-mail: liliang@tb123.org; Meiying Wu, Email:wu_my@126.com

\section{References}

1. World Health Organization. Global tuberculosis report 2018. WHO/HTM/TB/2018.20.Geneva: World Health Organization; 2018. 
2. Pai M, Riley LW, Colford JM Jr. Interferon-gamma assays in the immunodiagnosis of tuberculosis: a systematic review. Lancet Infect Dis. 2004;4(12):761-776.

3. Mazurek GH, Jereb J, Vernon A, et al. IGRA Expert Committee;Centers for Disease Control and Prevention (CDC). Updated guidelines for using interferon gamma release assays to detect Mycobacterium tuberculosis infection-United States, 2010. MMWR Recomm Rep. 2010;59(RR-5):125.

4. 4. Lee JY, Choi HJ, Park IN, et al. Comparison of two commercial interferon-y assays for diagnosing Mycobacterium tuberculosis infection. Eur Respir J.2006;28(1): 24-30.

5. Chinese Medical Association. Clinical diagnosis standard of TB for clinical technology operation (TB volumes). People's Medical Publishing House. 2005.

6. T-SPOT Package Insert. Available from: http://www.tspot.com/ wp-content/uploads/2012/01/PI-TBUS-v4.pdf. [Last accessed on 2017 Sep 10].

7. Andersen P, Munk ME, Pollock JM, et al. Specific immune-based diagnosis of tuberculosis. Lancet.2000;356(9235):1099-1104.

8. 8. Uvarova EA, Belavin PA, Permyakova NV, et al. Oral immunogenicity of plant-made Mycobacterium tuberculosis ESAT-6 and CFP10. Biomed Res Int.2013; 2013:316304.

9. 9. Pym AS, Brodin P, Majlessi L, et al. Recombinant BCG exporting ESAT-6 confers enhanced protection against tuberculosis. Nat Med.2003; 9(5):533-539.

10. Andersen $P, A$ dersen $A B$, Sorensen $A L$, et al. Recall of longlived immunity to Mycobacterium tuberculosis in mice. J Immunol.1995; 154(7):3359-3372.

11. 1 Gupta N, Vedi S, Kunimoto DY, et al. Novel lipopeptides of ESAT-6 induce strong protective immunity against Mycobacterium tuberculosis: routes of immunization and TLR agonists critically impact vaccine's efficacy. Vaccine.2016; 34(46):5677-5688.

12. 1 Wang $X$, Barnes PF, Dobos-Elder KM, et al. ESAT-6 inhibits production of IFN- $y$ by Mycobacterium tuberculosis-responsive human T cells. J Immunol.2009; 182(6):3668-3677.

13. 1 Kumar P, Agarwal R, Siddiqui I, et al. ESAT6 differentially inhibits IFN- - -inducible Class II transactivator isoforms in both a TLR2-dependent and -independent manner. Immunol Cell Biol. 2012; 90(4):411-420.

14. Guo S, Xue R, Li Y, et al. The CFP/ESAT6 complex of Mycobacterium tuberculosis may function as a regulator of macrophage cell death at different stages of tuberculosis infection. Med Hypotheses. 2012; 78(3):389-392.

15. Wang $X$, Barnes PF, Huang F, et al. Early secreted antigenic target of 6-kDa protein of Mycobacterium tuberculosis primes dendritic cells to stimulate Th17 and inhibit Th1 immune responses. J Immunol.2012; 189(6):3092-3103.

16. Samten B, Wang X, Barnes PF. Immune regulatory activities of early secreted antigen target of 6-kD protein of Mycobacterium tuberculosis and implications for tuberculosis vaccine design. Tuberculosis.2011; 91(S1):s114-118. 
17. Abebe F, Belay M, Legesse M, et al. Association of ESAT-6/CFP-10 induced IFN- $\gamma$, TNF- $\alpha$ and IL-10 with clinical tuberculosis: evidence from cohorts of pulmonary tuberculosis patients, household contacts and community controls in an endemic setting. Clin Exp Immuno.2017;189(2):241-249.

18. 1 Pathan AA, Wilkinson KA, Klenerman P, et al. Direct ex vivo analysis of antigen-specific IFN-gammasecreting CD4 T cells in Mycobacterium tuberculosis-infected individuals: Associations with clinical disease state and effect of treatment. J Immunol.2001; 167(9):5217-5225.

19. Diel R., Loddenkemper R, Nienhaus A. Evidence-based comparison of commercial interferon-gamma release assays for detecting active TB: a meta analysis. Chest. 2010;137(4):952-968.

20. Nicol MP, Pienaar D, Wood K, et al. Enzyme-linked immunospot assay responses to early secretory antigenic target 6 , culture filtrate protein 10 , and purified protein derivative among children with tuberculosis: implications for diagnosis and monitoring of therapy. Clin Infect Dis.2005;40(9):13011308.

21. Chee CB,Barkham TM,Khinmar KW, et al. Quantitative T-cell interferon-gamma responses to Mycobacterium tuberculosis-specific antigens in active and latent tuberculosis. Eur $\mathrm{J}$ Clin Microbiol Infect Dis.2009;28(6):667-670.

22. 2 Hill PC,Fox A,Jeffries DJ, et al. Quantitative T cell assay reflects infectious load of Mycobacterium tuberculosis in an endemic case contact model. Clin Infect Dis. 2005;40(2):273-278.

23. 2 Qiu Y, Wang Y, Lin N, et al. Multicenter clinical evaluation of three commercial reagent kits based on the interferon-gamma release assay for the rapid diagnosis of tuberculosis in China. Int $\mathrm{J}$ Infect Dis. 2015,40:108-112

24. Wards BJ, de Lisle GW, Collins DM. An esat6 knockout mutant of Mycobacterium bovis produced by homologous recombination will contribute to the development of a live tuberculosis vaccine. Tuber Lung Dis. 2000;80(4-5):185-189.

25. Berhet FX, Rasmussen PB, Rosenkrands I, et al. A Mycobacterium tuberculosis operon encoding ESAT-6 and a novel low-molecular-mass culture filtrate protein (CFP-10). Microbiol,1998;144(Pt 11):3195-3203.

26. Di L, Li Y. The risk factor of false-negative and false-positive for T-SPOT.TB in active tuberculosis. J Clin Lab Anal. 2018 ,32(2):1-7.

27. Linton PJ, Dorshkind K. Age-related changes in lymphocyte development and function. Nat Immunol. 2004;5(2):133-139.

28. Hang NT,Lien LT,Kobayashi N, et al. Analysis of factors lowering sensitivity of interferon- $\gamma$ release assay for tuberculosis. PloS One. 2011;6(8):e23806.

29. 2 Kobashi Y, Mouri K, Yagi S, et al. Clinical utility of the QuantiFERON TB-2G test for elderly patients with active tuberculosis. Chest 2008;133(5):1196-1202.

30. Kobashi Y, Mouri K, Miyashita N, et al. QuantiFERON TB-2G test for patients with active tuberculosis stratified by age groups. Scand J Infect Dis. 2009;41(11-12):841-846.

31. Kamiya $\mathrm{H}$, Ikushima $\mathrm{S}$, Kondo $\mathrm{K}$, et al. Diagnostic performance of interferon-gamma release assays in elderly populations in comparison with younger populations. J Infect hemother.2013; 19(2):217- 
222.

\section{Tables}

Table 1 Clinical characteristics of PTB patients $(n=1252)$ 


\begin{tabular}{|c|c|}
\hline Variables & Frequency (\%) \\
\hline \multicolumn{2}{|l|}{ Gender } \\
\hline Male & $848(67.7)$ \\
\hline Female & $404(32.3)$ \\
\hline \multicolumn{2}{|l|}{ Age } \\
\hline$<45$ & $670(53.5)$ \\
\hline $45-65$ & $386(30.8)$ \\
\hline$>65$ & $196(15.7)$ \\
\hline \multicolumn{2}{|l|}{ Bacterial culture } \\
\hline Positive & $716(57.2)$ \\
\hline Negative & $536(42.8)$ \\
\hline \multicolumn{2}{|c|}{ Sputum-smear microscopy (AFB) } \\
\hline Negative & $551(44.0)$ \\
\hline+ & $221(17.7)$ \\
\hline++ & $196(15.7)$ \\
\hline+++ & $172(13.7)$ \\
\hline++++ & $112(8.9)$ \\
\hline \multicolumn{2}{|l|}{ Range of TB } \\
\hline $1-2$ & $504(40.3)$ \\
\hline $3-4$ & $326(26.0)$ \\
\hline $5-6$ & $422(33.7)$ \\
\hline \multicolumn{2}{|c|}{ Lung cavity and its range } \\
\hline 0 & $710(56.7)$ \\
\hline $1-2$ & $442(35.3)$ \\
\hline $3-4$ & $69(5.5)$ \\
\hline $5-6$ & $31(2.5)$ \\
\hline \multicolumn{2}{|l|}{ T-SPOT.TB A } \\
\hline Negative (0-5 SFUs) & $193(15.4)$ \\
\hline+ (6-19 SFUs) & $250(20.0)$ \\
\hline$++(20-39$ SFUs $)$ & $256(20.4)$ \\
\hline$+++(40-69$ SFUs $)$ & $238(19.0)$ \\
\hline$++++(\geq 70$ SFUs $)$ & $315(25.2)$ \\
\hline \multicolumn{2}{|l|}{ T-SPOT.TB В } \\
\hline Negative (0-5 SFUs) & 245 (19.6) \\
\hline+ (6-19 SFUs) & $260(20.8)$ \\
\hline
\end{tabular}




$\begin{array}{ll}++(20-39 \text { SFUs }) & 190(15.2) \\ +++(40-69 \text { SFUs }) & 176(14.1) \\ ++++(\geq 70 \text { SFUs }) & 381(30.4)\end{array}$

TB Tuberculosis,AFB sputum-smear microscopy,SFUs spot-forming units

Table 2. Trends between clinical characteristics in PTB patients and T-SPOT.TB A ( $\mathrm{n}=1252)$ 


\begin{tabular}{|c|c|c|c|c|c|c|c|c|c|}
\hline \multirow{2}{*}{$\begin{array}{l}\text { Variables } \\
\\
\text { Sputum-smear } \\
\text { microscopy } \\
(\mathrm{AFB})\end{array}$} & \multicolumn{5}{|c|}{$\begin{array}{l}\text { T-SPOT.TB A } \\
\text { Frequency (\%) }\end{array}$} & \multicolumn{2}{|c|}{$\begin{array}{l}\text { Jonckheere-Terpstra } \\
\text { test or chi-square test } \\
\text { for trend }\end{array}$} & \multicolumn{2}{|c|}{$\begin{array}{l}\text { Spearman rank order } \\
\text { correlation or chi- } \\
\text { square test }\end{array}$} \\
\hline & - & + & ++ & +++ & ++++ & $\mathrm{T}_{\mathrm{JT}}$ or $\chi^{2}$ & $P$ & $r_{s}$ or $\chi^{2}$ & $P$ \\
\hline- & $\begin{array}{l}96 \\
(49.7)\end{array}$ & $\begin{array}{l}134 \\
(53.6)\end{array}$ & $\begin{array}{l}112 \\
(43.8)\end{array}$ & $\begin{array}{l}104 \\
(43.7)\end{array}$ & $\begin{array}{l}105 \\
(33.3)\end{array}$ & $345784^{\mathrm{a}}$ & $<0.001$ & $0.141^{\mathrm{c}}$ & $<0.001$ \\
\hline+ & $\begin{array}{l}24 \\
(12.4)\end{array}$ & $\begin{array}{l}46 \\
(18.4)\end{array}$ & $\begin{array}{l}53 \\
(20.7)\end{array}$ & $\begin{array}{l}47 \\
(19.7)\end{array}$ & $\begin{array}{l}51 \\
(16.2)\end{array}$ & & & & \\
\hline++ & $\begin{array}{l}39 \\
(20.2)\end{array}$ & $\begin{array}{l}31 \\
(12.4)\end{array}$ & $\begin{array}{l}33 \\
(12.9)\end{array}$ & $\begin{array}{l}30 \\
(12.6)\end{array}$ & $\begin{array}{l}63 \\
(20.0)\end{array}$ & & & & \\
\hline+++ & $\begin{array}{l}21 \\
(10.9)\end{array}$ & $\begin{array}{l}19 \\
(7.6)\end{array}$ & $\begin{array}{l}32 \\
(12.5)\end{array}$ & $\begin{array}{l}35 \\
(14.7)\end{array}$ & $\begin{array}{l}65 \\
(20.6)\end{array}$ & & & & \\
\hline++++ & $\begin{array}{l}13 \\
(6.8)\end{array}$ & $\begin{array}{l}20 \\
(8.0)\end{array}$ & $\begin{array}{l}26 \\
(10.1)\end{array}$ & $\begin{array}{l}22 \\
(9.3)\end{array}$ & $\begin{array}{l}31 \\
(9.9)\end{array}$ & & & & \\
\hline Bacterial cultur & & & & & & & & & \\
\hline- & $\begin{array}{l}100 \\
(51.8)\end{array}$ & $\begin{array}{l}119 \\
(47.6)\end{array}$ & $\begin{array}{l}117 \\
(45.7)\end{array}$ & $\begin{array}{l}89 \\
(37.4)\end{array}$ & $\begin{array}{l}111 \\
(35.2)\end{array}$ & $18.978^{d}$ & $<0.001$ & $19.835^{\mathrm{b}}$ & 0.001 \\
\hline+ & $\begin{array}{l}93 \\
(48.2)\end{array}$ & $\begin{array}{l}131 \\
(52.4)\end{array}$ & $\begin{array}{l}139 \\
(54.3)\end{array}$ & $\begin{array}{l}149 \\
(62.6)\end{array}$ & $\begin{array}{l}204 \\
(64.8)\end{array}$ & & & & \\
\hline Range of $\mathrm{PTB}^{\mathrm{e}}$ & & & & & & & & & \\
\hline $1-2$ & $\begin{array}{l}70 \\
(36.3)\end{array}$ & $\begin{array}{l}116 \\
(46.4)\end{array}$ & $\begin{array}{l}113 \\
(44.1)\end{array}$ & $\begin{array}{l}97 \\
(40.8)\end{array}$ & $\begin{array}{l}108 \\
(34.3)\end{array}$ & $321236.5^{a}$ & 0.154 & $0.040^{\mathrm{C}}$ & 0.155 \\
\hline $3-4$ & $\begin{array}{l}55 \\
(28.5)\end{array}$ & $\begin{array}{l}54 \\
(21.6)\end{array}$ & $\begin{array}{l}67 \\
(26.2)\end{array}$ & $\begin{array}{l}59 \\
(24.8)\end{array}$ & $\begin{array}{l}91 \\
(28.9)\end{array}$ & & & & \\
\hline $5-6$ & $\begin{array}{l}68 \\
(35.2)\end{array}$ & $\begin{array}{l}80 \\
(32.0)\end{array}$ & $\begin{array}{l}76 \\
(29.7)\end{array}$ & $\begin{array}{l}82 \\
(34.4)\end{array}$ & $\begin{array}{l}116 \\
(36.8)\end{array}$ & & & & \\
\hline Range of cavity & & & & & & & & & \\
\hline 0 & $\begin{array}{l}112 \\
(58.0)\end{array}$ & $\begin{array}{l}152 \\
(60.8)\end{array}$ & $\begin{array}{l}157 \\
(61.3)\end{array}$ & $\begin{array}{l}133 \\
(55.9)\end{array}$ & $\begin{array}{l}156 \\
(49.5)\end{array}$ & $326079.5^{\mathrm{a}}$ & 0.023 & $0.064^{\mathrm{c}}$ & 0.024 \\
\hline $1-2$ & $\begin{array}{l}61 \\
(31.6)\end{array}$ & $\begin{array}{l}76 \\
(30.4)\end{array}$ & $\begin{array}{l}86 \\
(33.6)\end{array}$ & $\begin{array}{l}90 \\
(37.8)\end{array}$ & $\begin{array}{l}129 \\
(41.0)\end{array}$ & & & & \\
\hline $3-4$ & $\begin{array}{l}13 \\
(6.7)\end{array}$ & $\begin{array}{l}16 \\
(6.4)\end{array}$ & $\begin{array}{l}8 \\
(3.1)\end{array}$ & $\begin{array}{l}12 \\
(5.0)\end{array}$ & $\begin{array}{l}20 \\
(6.3)\end{array}$ & & & & \\
\hline $5-6$ & $\begin{array}{l}7 \\
(3.7)\end{array}$ & $\begin{array}{l}6 \\
(2.4)\end{array}$ & $\begin{array}{l}5 \\
(2.0)\end{array}$ & $\begin{array}{l}3 \\
(1.3)\end{array}$ & $\begin{array}{l}10 \\
(3.2)\end{array}$ & & & & \\
\hline
\end{tabular}

Gender 


\begin{tabular}{|c|c|c|c|c|c|c|c|c|c|}
\hline Male & $\begin{array}{l}130 \\
(67.4)\end{array}$ & $\begin{array}{l}171 \\
(68.4)\end{array}$ & $\begin{array}{l}171 \\
(66.8)\end{array}$ & $\begin{array}{l}160 \\
(67.2)\end{array}$ & $\begin{array}{l}216 \\
(68.6)\end{array}$ & $0.028^{d}$ & 0.868 & $0.295^{\mathrm{b}}$ & 0.990 \\
\hline \multirow[t]{2}{*}{ Female } & 63 & 79 & 85 & 78 & 99 & & & & \\
\hline & $(32.6)$ & (31.6) & (33.2) & (32.8) & (31.4) & & & & \\
\hline \multicolumn{10}{|l|}{ Age } \\
\hline \multirow[t]{2}{*}{$<45$} & 84 & 115 & 154 & 139 & 178 & $204306^{a}$ & $<0.001$ & $-0.124^{\mathrm{c}}$ & $<0.001$ \\
\hline & $(43.5)$ & $(46.0)$ & $(60.2)$ & (58.4) & (56.5) & & & & \\
\hline \multirow[t]{2}{*}{$45-65$} & 58 & 85 & 74 & 65 & 104 & & & & \\
\hline & $(30.1)$ & $(34.0)$ & (28.9) & (27.3) & (33.0) & & & & \\
\hline \multirow[t]{2}{*}{$>65$} & 51 & 50 & 28 & 34 & 33 & & & & \\
\hline & (26.4) & (20.0) & (10.9) & (14.3) & (10.5) & & & & \\
\hline
\end{tabular}

${ }^{a}$ Jonckheere-Terpstra test, ${ }^{b}$ chi-square test, ${ }^{c}$ Spearman rank order correlation, ${ }^{d}$ chi-square test for trend, ${ }^{e}$ According to the number of lung fields involved by PTB, ${ }^{\mathrm{f}}$ According to the number of lung fields involved by the cavity

Table 3. Trends between clinical characteristics in PTB patients and T-SPOT.TB B $(n=1252)$ 


\begin{tabular}{|c|c|c|c|c|c|c|c|c|c|}
\hline \multirow{2}{*}{$\begin{array}{l}\text { Variables } \\
\\
\text { Sputum-smear } \\
\text { microscopy } \\
\text { (AFB) }\end{array}$} & \multicolumn{5}{|c|}{$\begin{array}{l}\text { T-SPOT.TB B } \\
\text { Frequency (\%) }\end{array}$} & \multicolumn{2}{|c|}{$\begin{array}{l}\text { Jonckheere-Terpstra } \\
\text { test or chi-square test } \\
\text { for trend }\end{array}$} & \multicolumn{2}{|c|}{$\begin{array}{l}\text { Spearman rank order } \\
\text { correlation or chi- } \\
\text { square test }\end{array}$} \\
\hline & - & + & ++ & +++ & ++++ & $\mathrm{T}_{\mathrm{JT}}$ or $\chi^{2}$ & $P$ & $r_{s}$ or $\chi^{2}$ & $P$ \\
\hline- & $\begin{array}{l}125 \\
(51.0)\end{array}$ & $\begin{array}{l}115 \\
(44.2)\end{array}$ & $\begin{array}{l}80 \\
(42.1)\end{array}$ & $\begin{array}{l}87 \\
(49.4)\end{array}$ & $\begin{array}{l}144 \\
(37.8)\end{array}$ & $336017^{a}$ & $<0.001$ & $0.121^{\mathrm{c}}$ & $<0.001$ \\
\hline+ & $\begin{array}{l}38 \\
(15.5)\end{array}$ & $\begin{array}{l}55 \\
(21.2)\end{array}$ & $\begin{array}{l}36 \\
(18.9)\end{array}$ & $\begin{array}{l}36 \\
(20.5)\end{array}$ & $\begin{array}{l}56 \\
(14.7)\end{array}$ & & & & \\
\hline++ & $\begin{array}{l}46 \\
(18.8)\end{array}$ & $\begin{array}{l}38 \\
(14.6)\end{array}$ & $\begin{array}{l}33 \\
(17.4)\end{array}$ & $\begin{array}{l}22 \\
(12.5)\end{array}$ & $\begin{array}{l}57 \\
(15.0)\end{array}$ & & & & \\
\hline+++ & $\begin{array}{l}24 \\
(9.8)\end{array}$ & $\begin{array}{l}36 \\
(13.8)\end{array}$ & $\begin{array}{l}26 \\
(13.7)\end{array}$ & $\begin{array}{l}15 \\
(8.5)\end{array}$ & $\begin{array}{l}71 \\
(18.6)\end{array}$ & & & & \\
\hline++++ & $\begin{array}{l}12 \\
(4.9)\end{array}$ & $\begin{array}{l}16 \\
(6.2)\end{array}$ & $\begin{array}{l}15 \\
(7.9)\end{array}$ & $\begin{array}{l}16 \\
(9.1)\end{array}$ & $\begin{array}{l}53 \\
(13.9)\end{array}$ & & & & \\
\hline Bacterial cultur & & & & & & & & & \\
\hline- & $\begin{array}{l}132 \\
(53.9)\end{array}$ & $\begin{array}{l}117 \\
(45.0)\end{array}$ & $\begin{array}{l}77 \\
(40.5)\end{array}$ & $\begin{array}{l}77 \\
(43.8)\end{array}$ & $\begin{array}{l}133 \\
(34.9)\end{array}$ & $19.677^{d}$ & $<0.001$ & $22.952^{\mathrm{b}}$ & $<0.001$ \\
\hline+ & $\begin{array}{l}113 \\
(46.1)\end{array}$ & $\begin{array}{l}143 \\
(55.0)\end{array}$ & $\begin{array}{l}113 \\
(59.5)\end{array}$ & $\begin{array}{l}99 \\
(56.2)\end{array}$ & $\begin{array}{l}248 \\
(65.1)\end{array}$ & & & & \\
\hline Range of $\mathrm{PTB}^{\mathrm{e}}$ & & & & & & & & & \\
\hline $1-2$ & $\begin{array}{l}106 \\
(43.3)\end{array}$ & $\begin{array}{l}100 \\
(38.5)\end{array}$ & $\begin{array}{l}80 \\
(42.1)\end{array}$ & $\begin{array}{l}81 \\
(46.0)\end{array}$ & $\begin{array}{l}137 \\
(36.0)\end{array}$ & $315197.5^{a}$ & 0.219 & $0.035^{\mathrm{c}}$ & 0.220 \\
\hline $3-4$ & $\begin{array}{l}58 \\
(23.7)\end{array}$ & $\begin{array}{l}68 \\
(26.2)\end{array}$ & $\begin{array}{l}54 \\
(28.4)\end{array}$ & $\begin{array}{l}45 \\
(25.6)\end{array}$ & $\begin{array}{l}101 \\
(26.5)\end{array}$ & & & & \\
\hline $5-6$ & $\begin{array}{l}81 \\
(33.0)\end{array}$ & $\begin{array}{l}92 \\
(35.3)\end{array}$ & $\begin{array}{l}56 \\
(29.5)\end{array}$ & $\begin{array}{l}50 \\
(28.4)\end{array}$ & $\begin{array}{l}143 \\
(37.5)\end{array}$ & & & & \\
\hline Range of cavity & & & & & & & & & \\
\hline 0 & $\begin{array}{l}141 \\
(57.6)\end{array}$ & $\begin{array}{l}148 \\
(56.9)\end{array}$ & $\begin{array}{l}116 \\
(61.1)\end{array}$ & $\begin{array}{l}109 \\
(61.9)\end{array}$ & $\begin{array}{l}196 \\
(51.4)\end{array}$ & $313180^{a}$ & 0.322 & $0.028^{\mathrm{C}}$ & 0.330 \\
\hline $1-2$ & $\begin{array}{l}77 \\
(31.4)\end{array}$ & $\begin{array}{l}94 \\
(36.2)\end{array}$ & $\begin{array}{l}58 \\
(30.5)\end{array}$ & $\begin{array}{l}59 \\
(33.5)\end{array}$ & $\begin{array}{l}154 \\
(40.4)\end{array}$ & & & & \\
\hline $3-4$ & $\begin{array}{l}17 \\
(6.9)\end{array}$ & $\begin{array}{l}12 \\
(4.6)\end{array}$ & $\begin{array}{l}9 \\
(4.7)\end{array}$ & $\begin{array}{l}7 \\
(4.0)\end{array}$ & $\begin{array}{l}24 \\
(6.3)\end{array}$ & & & & \\
\hline $5-6$ & $\begin{array}{l}10 \\
(4.1)\end{array}$ & $\begin{array}{l}6 \\
(2.3)\end{array}$ & $\begin{array}{l}7 \\
(3.7)\end{array}$ & $\begin{array}{l}1 \\
(0.6)\end{array}$ & $\begin{array}{l}7 \\
(1.8)\end{array}$ & & & & \\
\hline
\end{tabular}

Gender 


\begin{tabular}{|c|c|c|c|c|c|c|c|c|c|}
\hline Male & $\begin{array}{l}159 \\
(64.9)\end{array}$ & $\begin{array}{l}193 \\
(74.2)\end{array}$ & $\begin{array}{l}131 \\
(68.9)\end{array}$ & $\begin{array}{l}114 \\
(64.8)\end{array}$ & $\begin{array}{l}251 \\
(65.9)\end{array}$ & $0.783^{d}$ & 0.376 & $7.357^{\mathrm{b}}$ & 0.118 \\
\hline \multirow[t]{2}{*}{ Female } & 86 & 67 & 59 & 62 & 130 & & & & \\
\hline & $(35.1)$ & (25.8) & (31.1) & $(35.2)$ & $(34.1)$ & & & & \\
\hline \multicolumn{10}{|l|}{ Age } \\
\hline \multirow[t]{2}{*}{$<45$} & 107 & 128 & 107 & 114 & 214 & $206572^{\mathrm{a}}$ & $<0.001$ & $-0.115^{c}$ & $<0.001$ \\
\hline & $(43.7)$ & $(49.2)$ & (56.3) & (64.8) & (56.2) & & & & \\
\hline \multirow[t]{2}{*}{$45-65$} & 83 & 91 & 52 & 35 & 125 & & & & \\
\hline & (33.9) & $(35.0)$ & $(27.4)$ & (19.9) & (32.8) & & & & \\
\hline \multirow[t]{2}{*}{$>65$} & 55 & 41 & 31 & 27 & 42 & & & & \\
\hline & $(22.4)$ & (15.8) & (16.3) & (15.3) & (11.0) & & & & \\
\hline
\end{tabular}

${ }^{a}$ Jonckheere-Terpstra test, ${ }^{b}$ chi-square test, ${ }^{c}$ Spearman rank order correlation, ${ }^{d}$ chi-square test for trend, ${ }^{\mathrm{e}}$ According to the number of lung fields involved by PTB, ${ }^{\mathrm{f}}$ According to the number of lung fields involved by the cavity

Figures

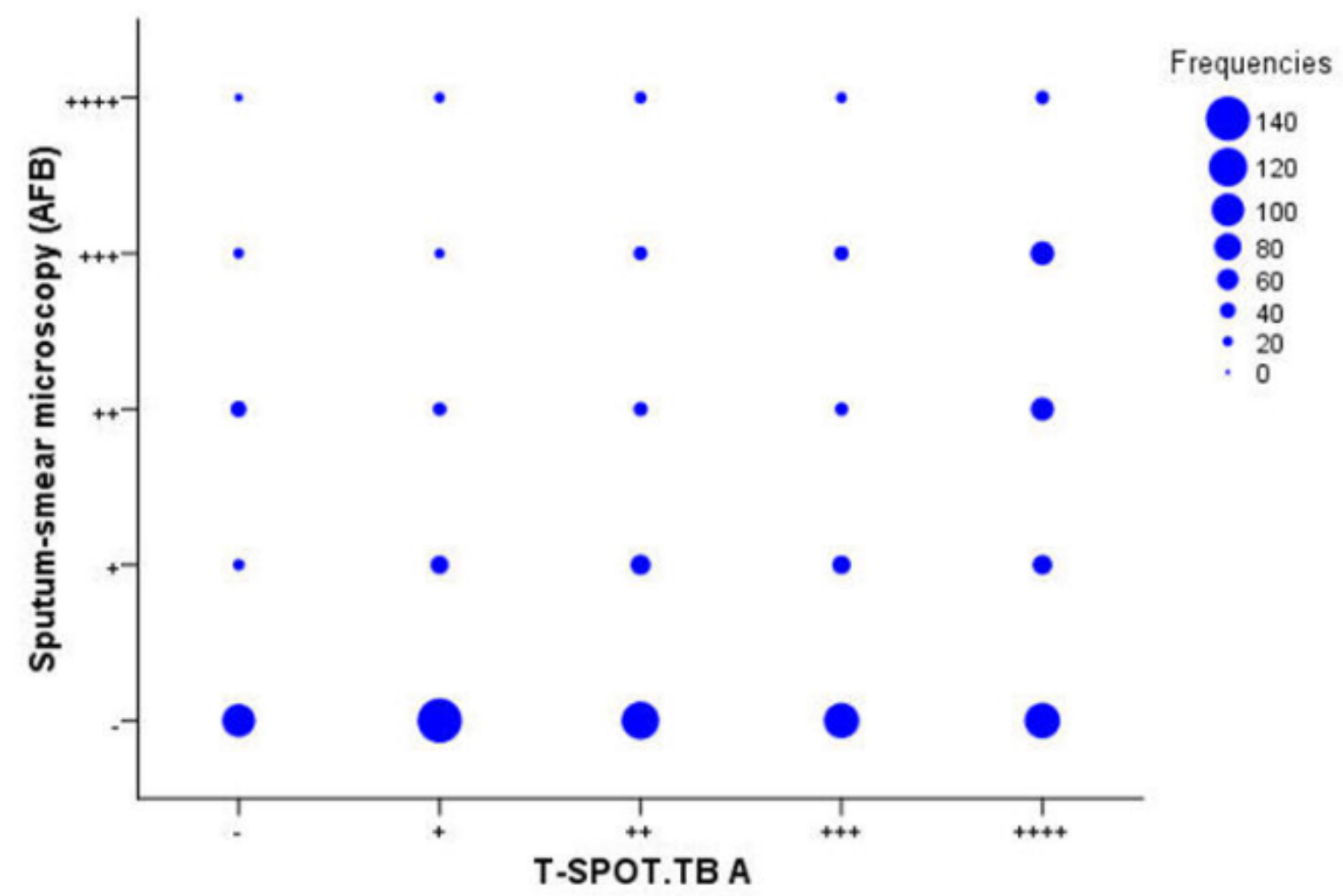

Fig.1 The trend between T-SPOT.TB A and Sputum-smear microscopy (AFB) 


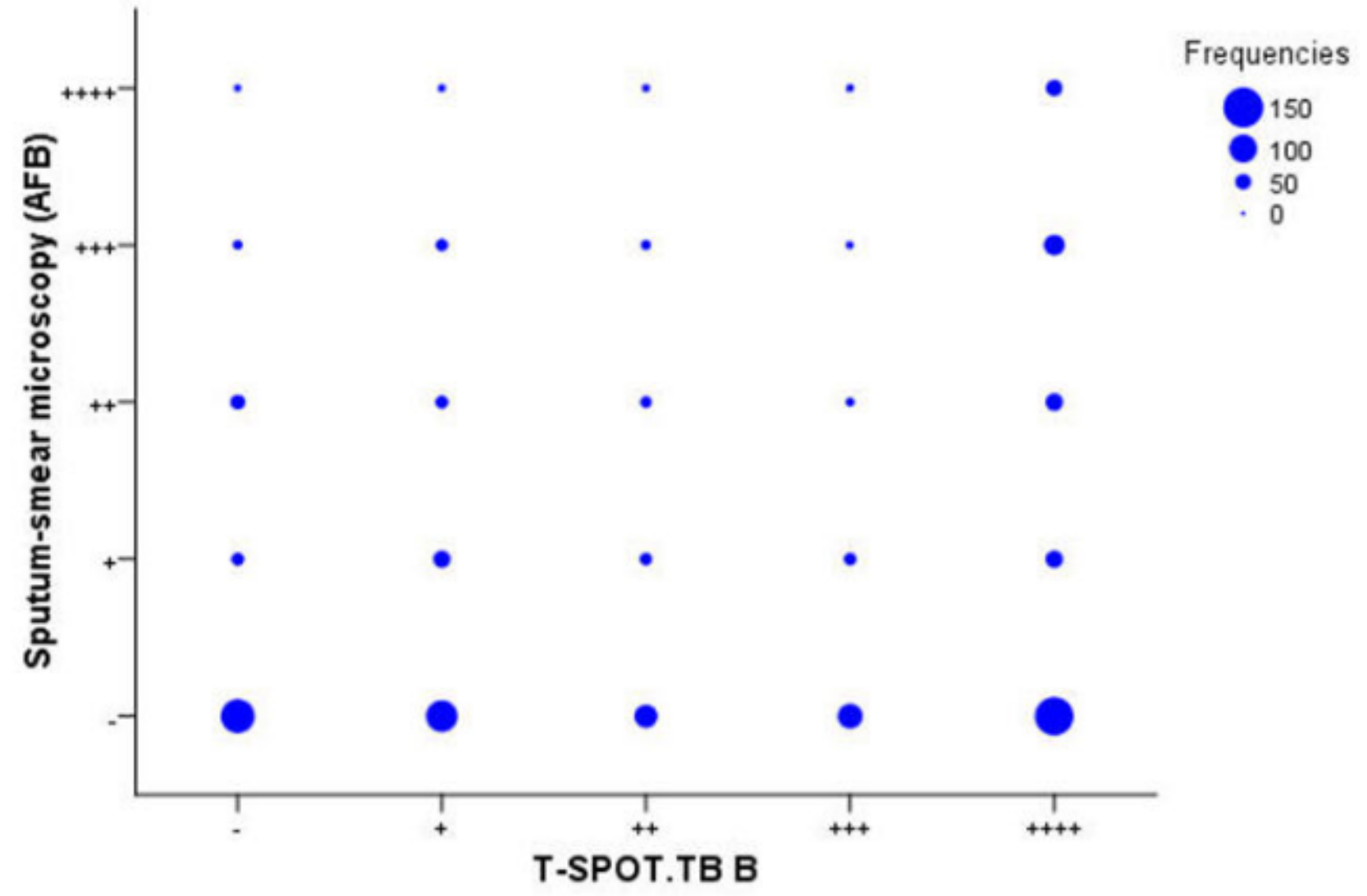

Fig.2 The trend between T-SPOT.TB B and Sputum-smear microscopy (AFB)

Figure 2 


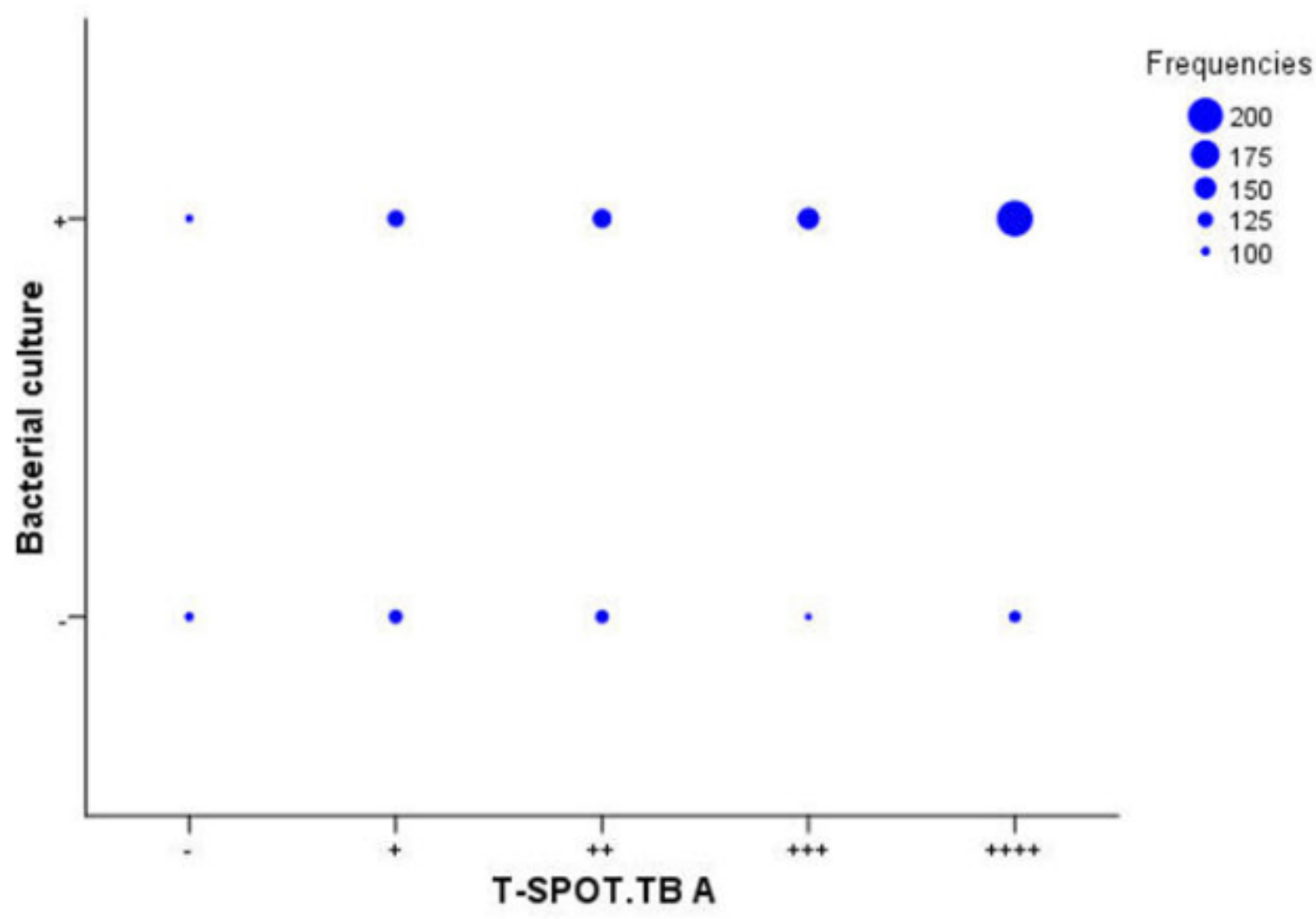

Fig.3 The trend between T-SPOT.TB A and Bacterial culture

Figure 3 


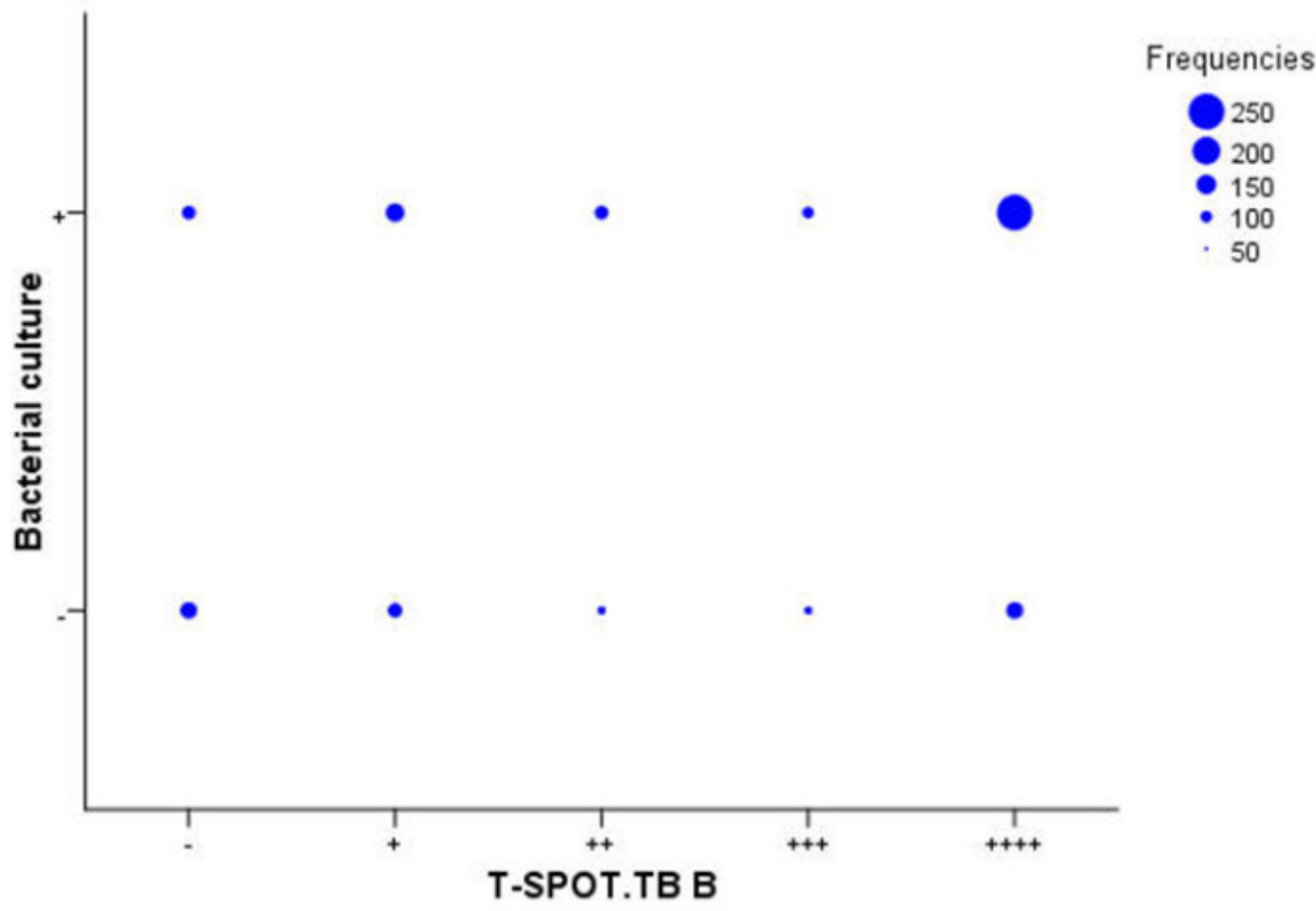

Fig.4 The trend between T-SPOT.TB B and Bacterial culture

Figure 4 


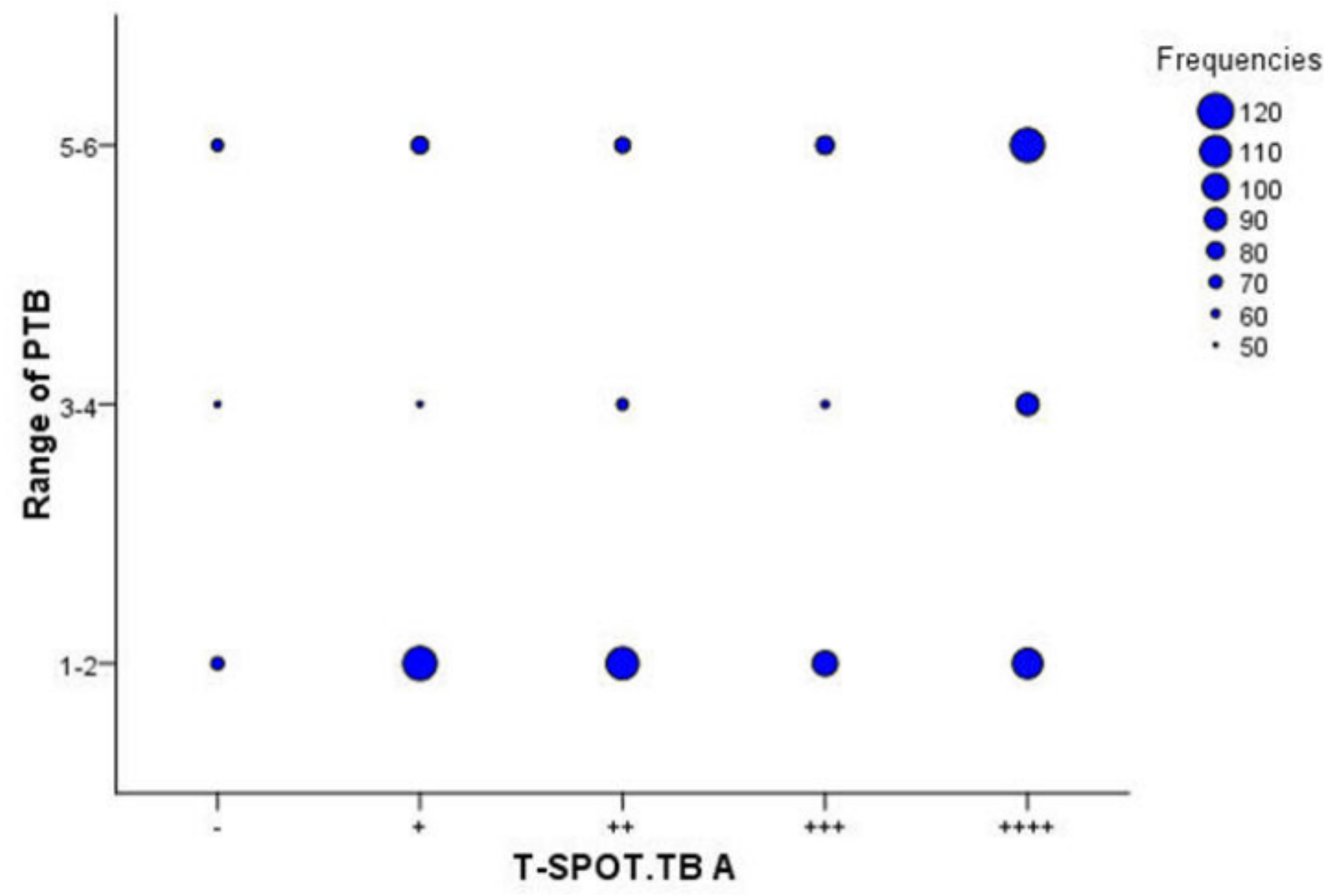

Fig.5 The trend between T-SPOT.TB A and Range of PTB

Figure 5 


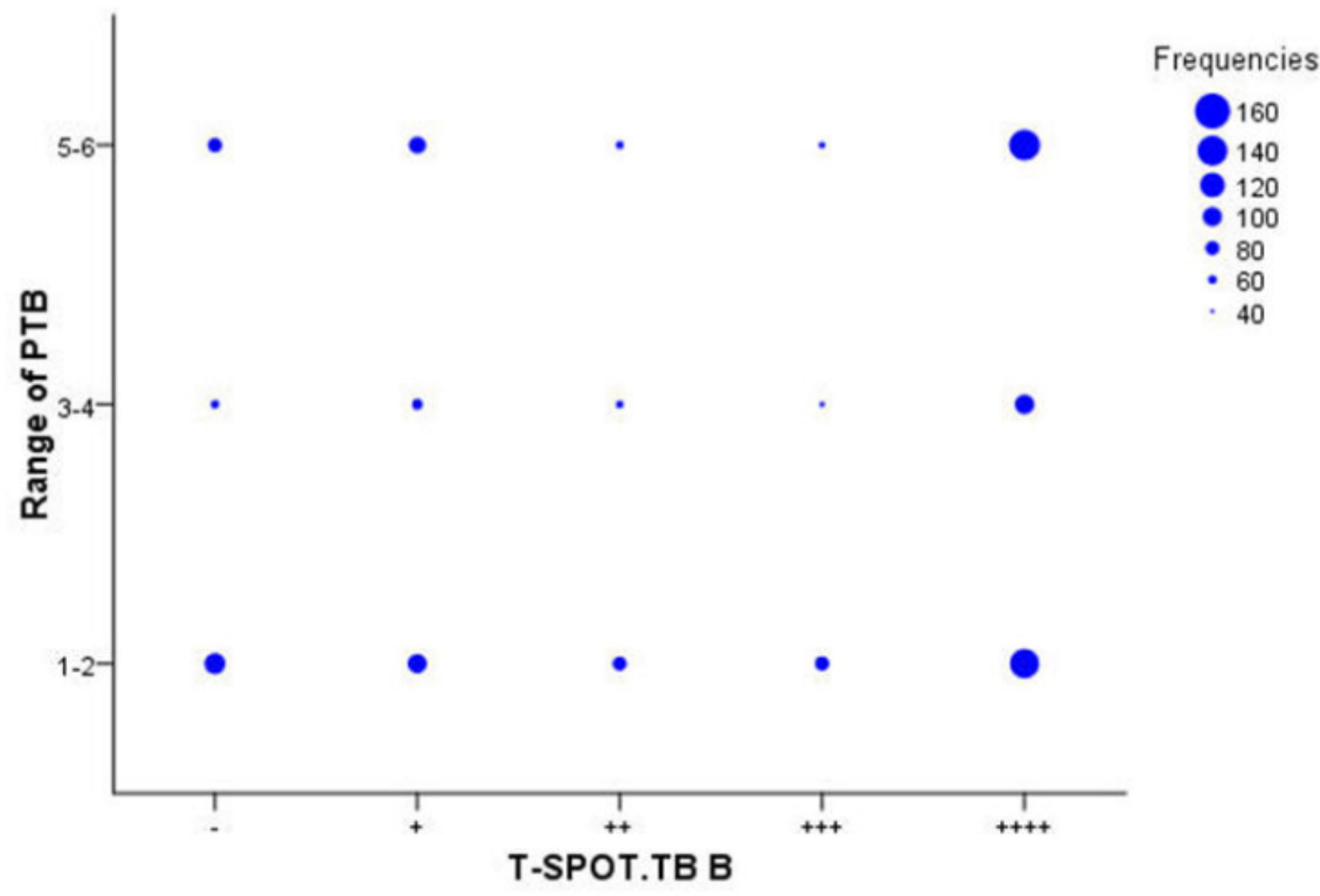

Fig.6 The trend between T-SPOT.TB B and Range of PTB

Figure 6 


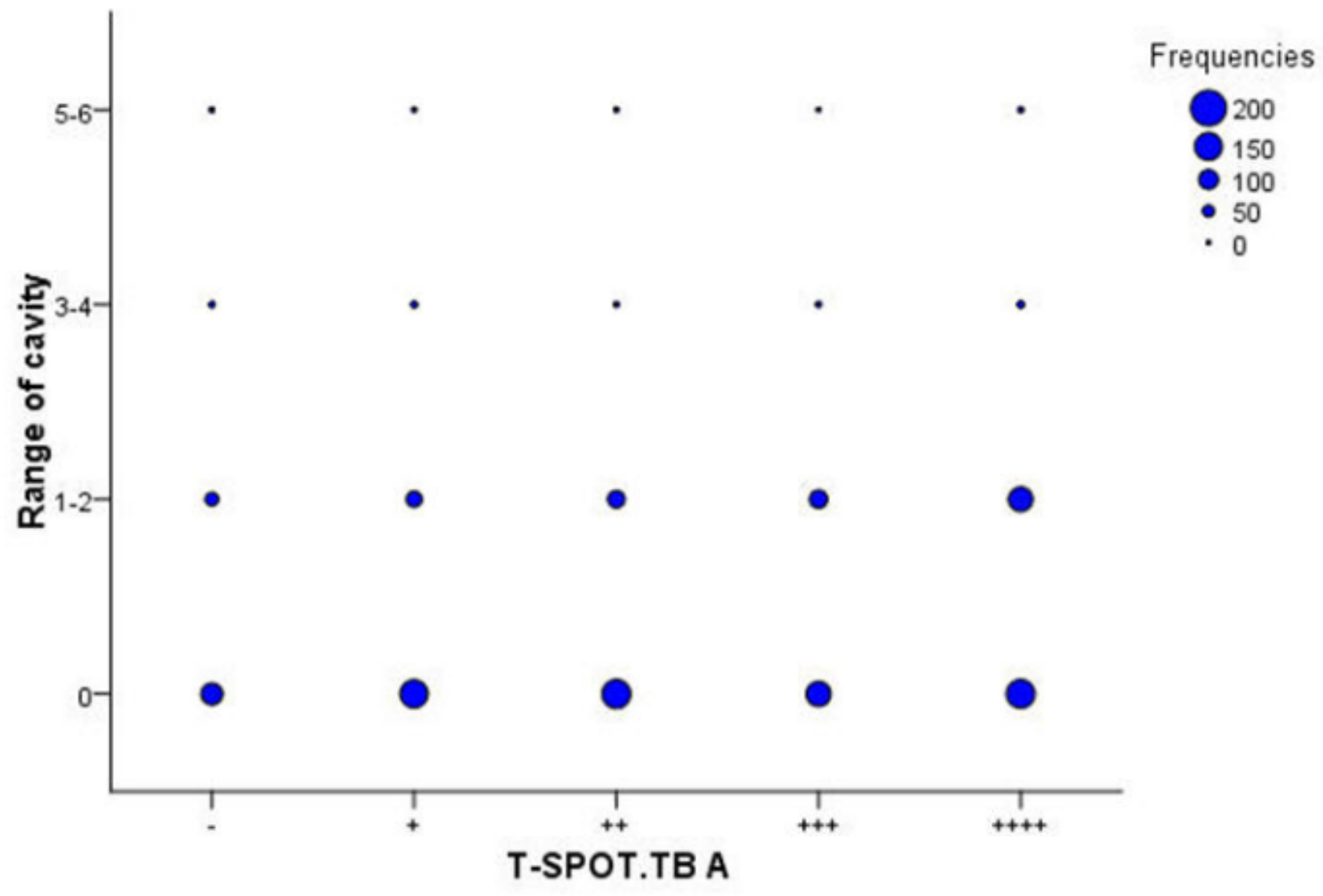

Fig.7 The trend between T-SPOT.TB A and Range of cavity

Figure 7 


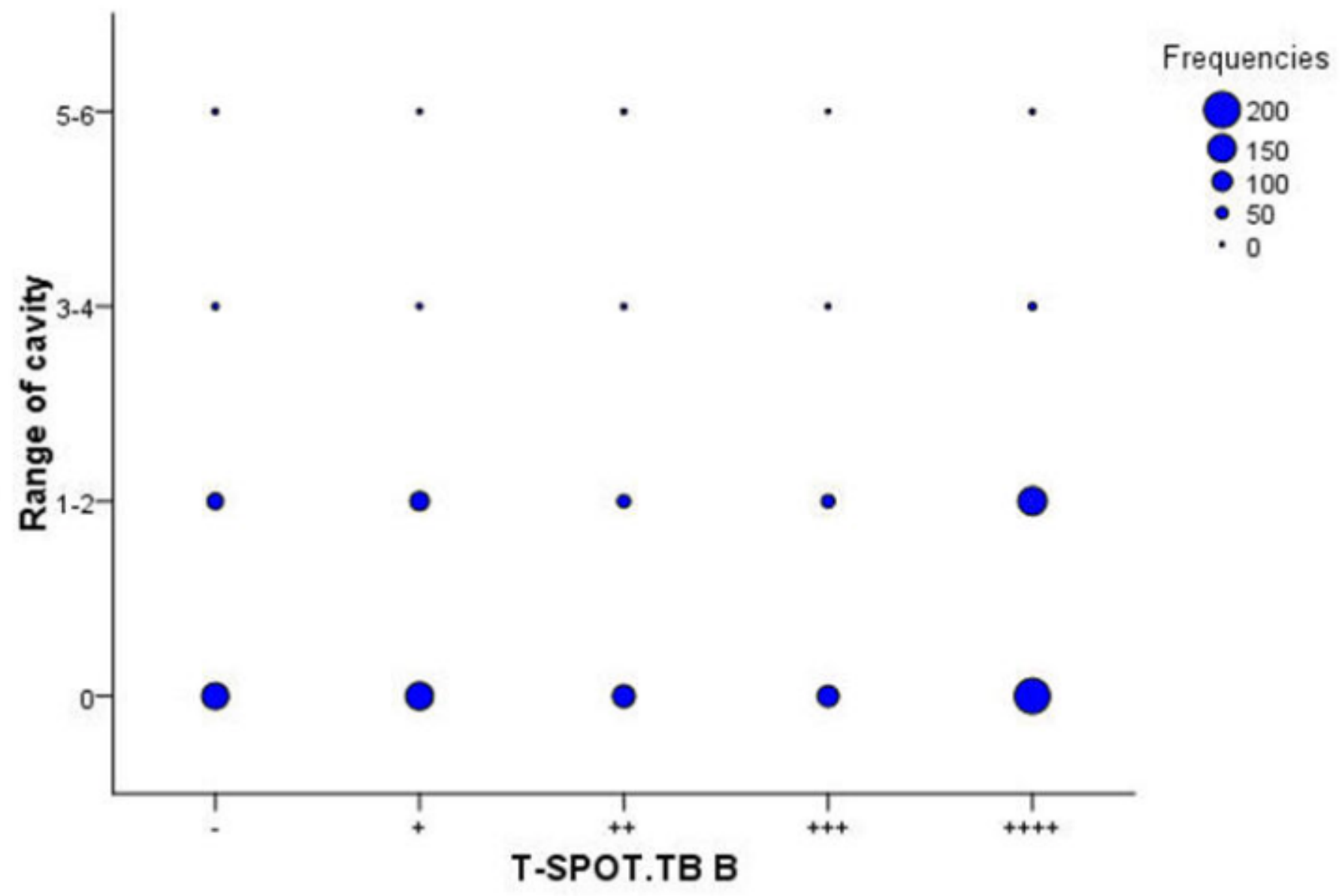

Fig. 8 The trend between T-SPOT.TB B and Range of cavity

Figure 8 


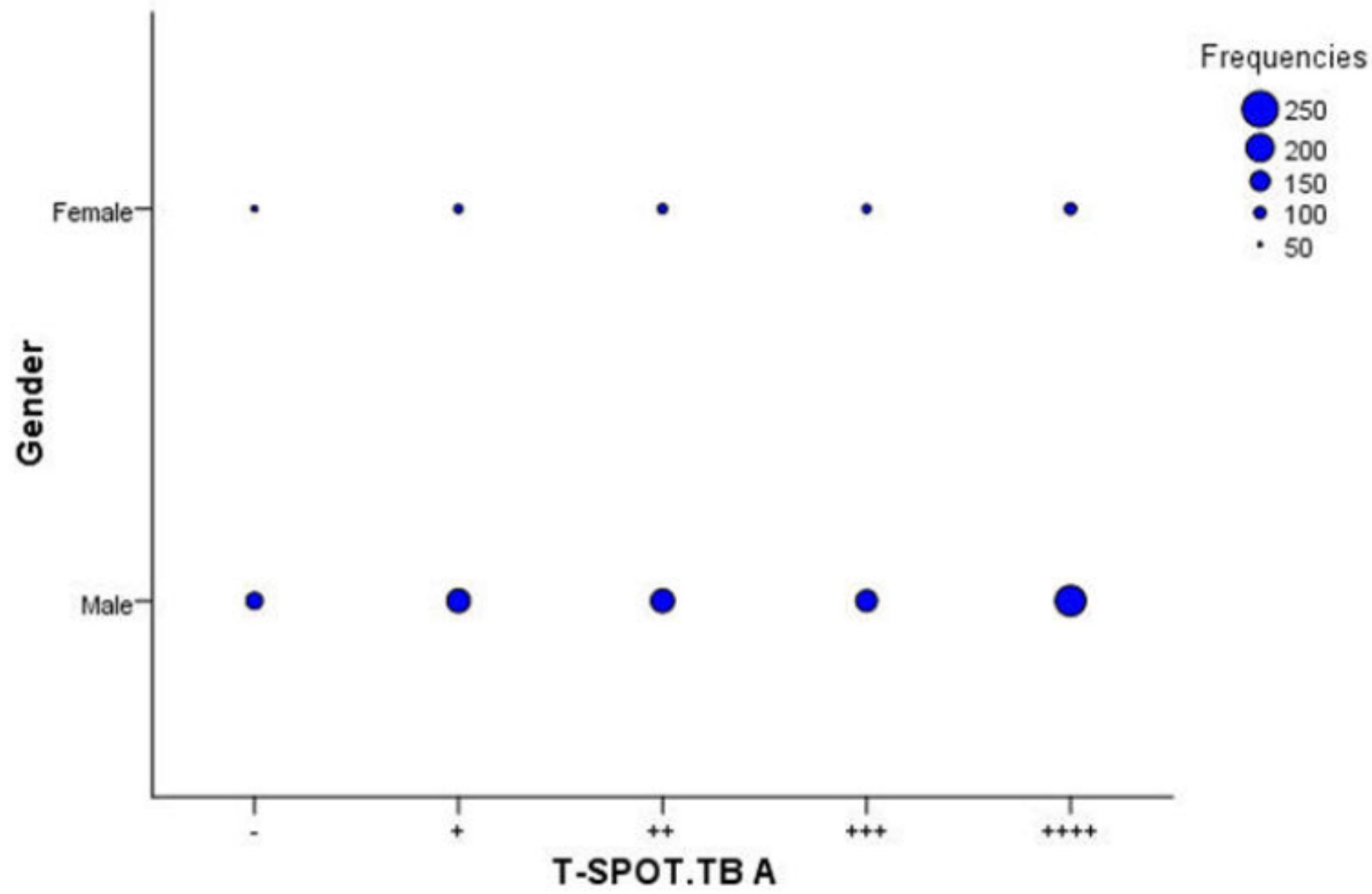

Fig.9 The trend between T-SPOT.TB A and Gender

Figure 9 


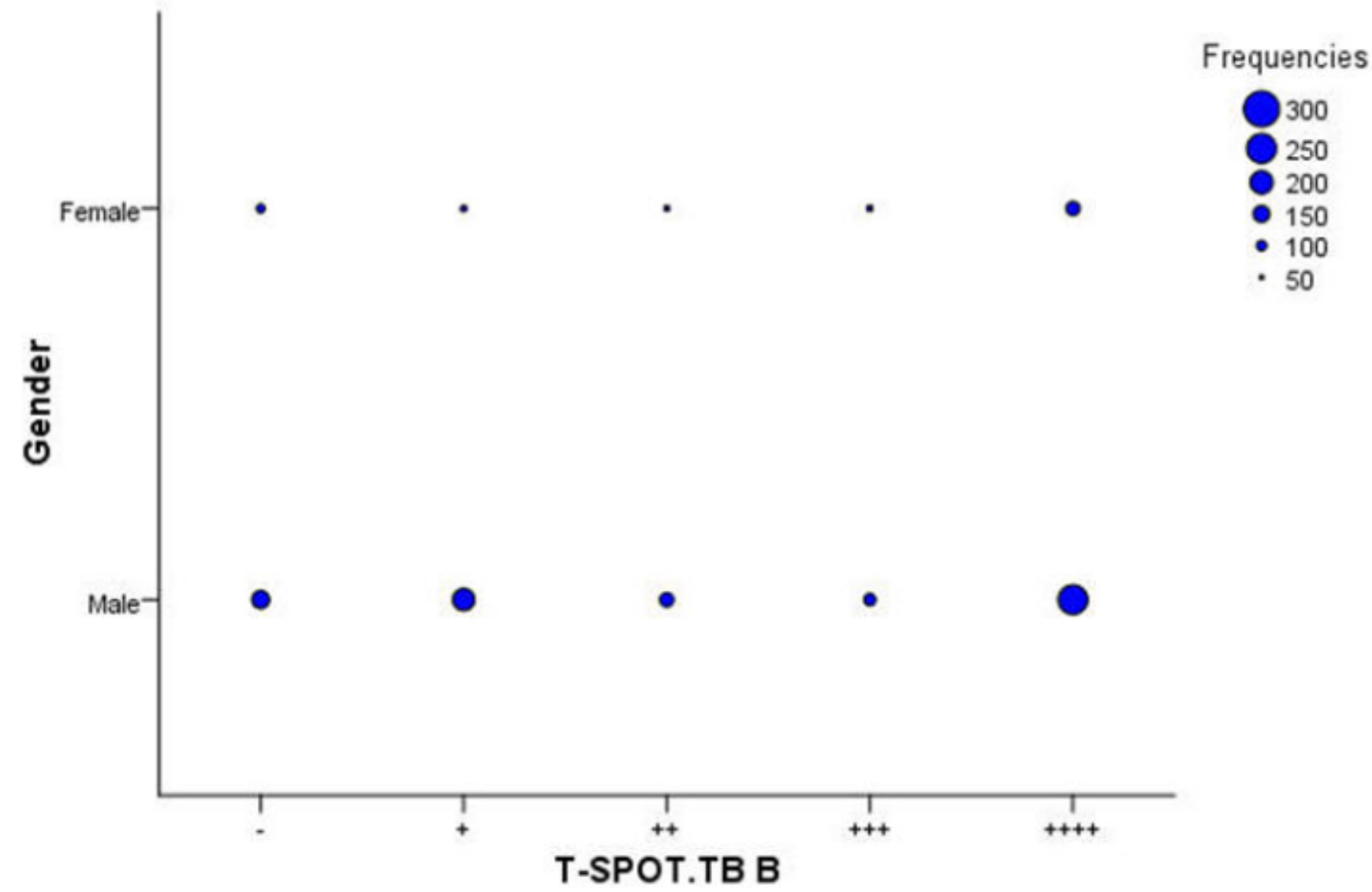

Fig.10 The trend between T-SPOT.TB B and Gender

Figure 10 


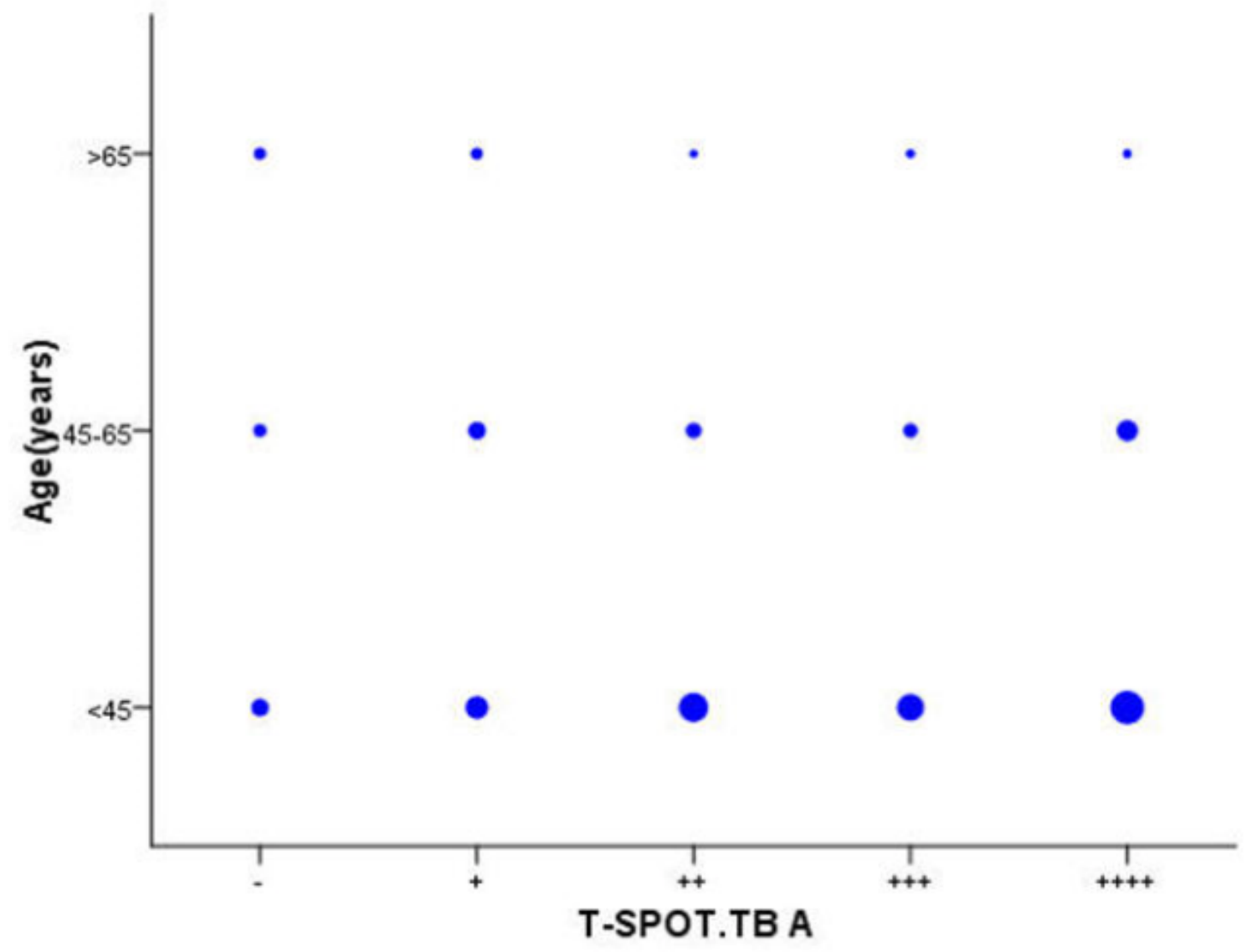

Frequencies

200

150

- 100

- 50

- 0

Fig11. The trend between T-SPOT.TB A and age

Figure 11 


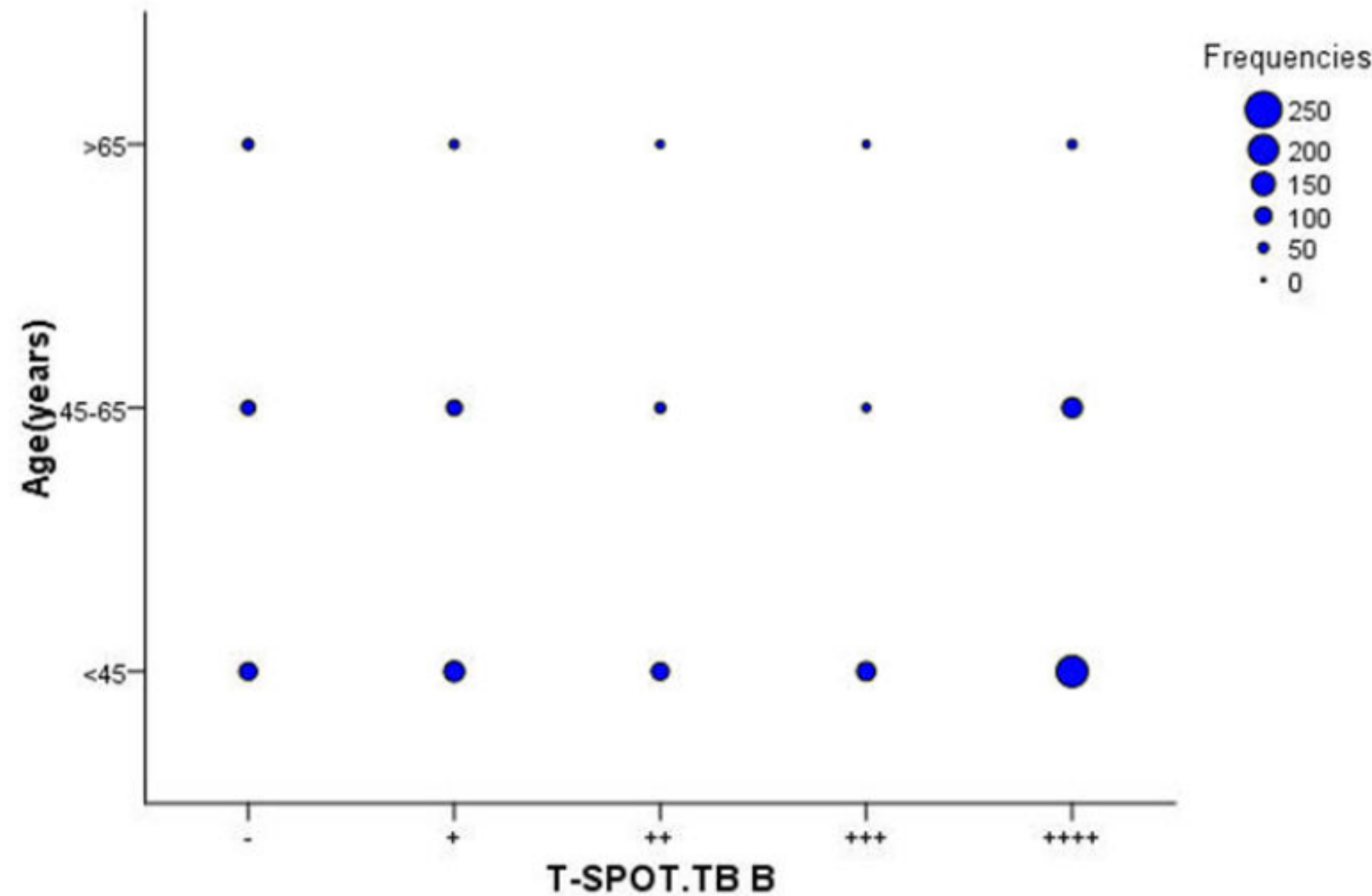

Fig12. The trend between T-SPOT.TB B and age

Figure 12 